\title{
Perceptions of Justice and Its Impact on Work Motivation among Lecturers at Universities in Hanoi, Vietnam
}

\author{
Thang Van Nguyen ${ }^{* 1}$, Endale Tadesse ${ }^{1}$, Wang Muhua ${ }^{1}$ \\ ${ }^{1}$ Department of Education Leadership and Management, Faculty of Education, Southwest University, \\ Chongqing, China
}

\begin{tabular}{|c|c|}
\hline Articl & Abstract \\
\hline Article & Purpose: The study had the fundamental purpose of investigating \\
\hline 25 October 2020 & perceptions of justice and its impact on work motivation among university \\
\hline 28 January 2021 & lectures in Hanoi, Vietnam. \\
\hline I: 30 January 2021 & $\begin{array}{l}\text { Methodology/Approach/Design: A quantitative research approach was } \\
\text { employed with survey questionnaire as a data collection tool. To achieve the }\end{array}$ \\
\hline$\overline{\text { Key }}$ & study objective, 416 lecturers who work at public and non-public \\
\hline $\begin{array}{l}\text { Perceived Organizational } \\
\text { Justice, }\end{array}$ & $\begin{array}{l}\text { universities in Hanoi were included in this study. The correlation coefficient } \\
\text { and multiple regression analysis were applied to measure the relationship }\end{array}$ \\
\hline Motivation, & between the lecturers' perceptions of justice and their work motivation. \\
\hline $\begin{array}{l}\text { Work Environment, } \\
\text { Higher Education }\end{array}$ & $\begin{array}{l}\text { Results: Findings indicated that perceptions of justice in payment, } \\
\text { recognition, opportunities for promotion, the attitudes, and treatments of }\end{array}$ \\
\hline Paper Type: & leaders had a significant and positive correlation with lecturers' work \\
\hline Research Article & $\begin{array}{l}\text { motivation. The study also showed that Vietnamese lecturers are more } \\
\text { concerned with non-monetary than monetary compensation, such as }\end{array}$ \\
\hline Corresponding Author: & $\begin{array}{l}\text { promotions, training, and professional development opportunities. } \\
\text { Practical Implications: This study presents implications for Vietnam's }\end{array}$ \\
\hline Thang Van Nguyen & $\begin{array}{l}\text { higher education authorities. The results might be of interest for any project } \\
\text { aiming at motivating faculty and improving their working conditions. }\end{array}$ \\
\hline $\begin{array}{l}\text { Email: } \\
\text { victor.work2051991@gmail.com }\end{array}$ & $\begin{array}{l}\text { Originality/Value: The originality of the study is in the exploration of } \\
\text { perception of justice and its effect of lecturers' motivation. It is recognized } \\
\text { that providing a justice/fairness based environment will ensure that schools }\end{array}$ \\
\hline Tel: $(-$ & can motivate their lecturers. \\
\hline
\end{tabular}

\section{Introduction}

After 20 years of innovation and five years of implementation, the Higher Education Institutes (HEIs) in Vietnam has proved to be the most critical sector in sustainable development with an advantage for the country (MOET, 2005). The Government has been starting to focus on improving the Higher Education system. There has been investment in school infrastructure and facilities to promote quality standards education and training. The mechanisms and policies to meet the needs of teachers and lecturers have been comprehensively establishing. However, according to the data released by the Ministry of Education and Training (MOET Vietnam), in more than 200 universities, several lecturers who do not measure up to required standards are said to exist (according to Vietnamese Higher Education Law, the required qualifications for lecturers is master's degree or higher, except for some of the specific professionals). According to statistics of MOET, from the end of the 2017 to 2019 academic year, the number of the teaching staff was 73,312 lectures, an increase of 520 people 
compared with the previous year 2016-2017, of which about 21,106 lecturers hold a professional doctoral degree (accounting for $28.8 \%$ of the total).

This rate has not yet achieved the goal set. Based on the Decree No. 14/2015/ NQ-CP by the Government of Vietnam on fundamental and comprehensive reform of Higher Education in Vietnam for 2006 - 2020, in the year 2020, the rate of lecturers with a doctorate should reach at least 35 percent. The Ministry of Education and Training assessed that the proportion of lecturers with professors, associate professors, and doctoral levels in the whole system is still low. Besides, there is still a big question mark concerning lecturers' quality since many lecturers have a low-level of formal research experience expressed through the small number of publications in international journals (World Bank, 2008) and the poor performance in research papers (Anh, 2017). Therefore, this created massive gaps in the quality, quantity, and qualification of teaching staff between the Vietnamese HEIs, and ASEAN member states (Ngo, 2006). The study of Scimago (2017) indicated that there are widely evident weaknesses of the research performance resulting in lower scores than Thailand and Malaysia. One explanation for the quality of teaching staff limited is that there are still some shortcomings in the university policies and measures about establishing and maintaining the lecturers' motivation to enhance their performance (Hamano, 2008). Work motivation is considered a crucial concept for lecturers to do their job more productively and effectively (Al-Salameh, 2014; Tadesse, 2020). Lecturers with a high level of motivation will make an extra effort and feel satisfied so that they can do the job better than others (Levesque et al., 2004). Lacking motivation in an organization will lead to dissatisfaction at work and result in laziness deemed, absenteeism, low quality of teaching, and reduced commitment (Jesus \& Lens, 2005). Thus, it is essential to determine what factors increase the level of lecturer motivation.

Hence, the paramount purpose of this study was to find out the impact of perceptions of justice in paying salary, the process of paying salary, recognition, opportunities for promotion, the attitudes and treatments of colleagues, students, leadership, and society on the level of work motivation among lecturers working at universities in Hanoi, Vietnam. So based on the literature review we went through, the following assumption was made.

\section{Research Hypotheses}

- Hypothesis 1. Justice in paying a salary is positively associated with lecturers' work motivation.

- Hypothesis 2. Justice in the processing of paying a salary is positively associated with lecturers' work motivation.

- Hypothesis 3. Justice in recognition is positively associated with lecturers' work motivation.

- Hypothesis 4. Justice in opportunities for promotion is positively associated with lecturers' work motivation.

- Hypothesis 5. Justice in the attitude of colleagues is positively associated with lecturers' work motivation.

- Hypothesis 6. Justice in the behaviour and treatment of leadership is positively associated with lecturers' work motivation. 
- Hypothesis 7. Justice in the students' feedback is positively associated with lecturers' work motivation.

- Hypothesis 8. Justice in the attitude and assessment of society is positively associated with lecturers' work motivation.

\section{Theoretical Framework}

A considerable number of previous theories and researches have reported that forms of justice or fairness are the primary factor that influences the lecturers' motivation and job satisfaction (e.g., Akman, 2018; Colquitt, 2005; Greenberg, 2011; Latham \& Pinder, 2005). According to these studies, perceptions of justice that lecturers felt in school can be seen as a decisive factor for their sense of motivation while contributing their abilities and skills toward the school's success. Indeed, justice or fairness concepts are considered a foundation in literature reviews of work motivation (Latham \& Pinder005). People always tend to compare what they contribute to the organization (skills, experience, etc.) to what they receive (salary, rewards, etc.) (Henle, 2005). Similarly, lecturers enter the profession with abilities, knowledge, skills, and qualifications for which they deserve to have these qualities. According to Vroom's Expectancy Theory (1964), when lecturers feel that they are fairly rewarded based on their efforts and competencies, they will be motivated and satisfied. Conversely, when they perceive the reward and treatment are unfair, they will feel unmotivated and dissatisfied with the current job. As a result of this relationship, it can be interpreted that an increase in perceptions of justice in school followed a considerable increase in lecturers' work motivation.

According to lecturers' opinions, there is limited research considering the effects of justice or fairness on work motivation at universities in Vietnam. Likewise, it has been thought that discovering the relationship between the work motivation of lecturers and justice based environment in school altogether is necessary and prominent for the effectiveness of the school. Therefore, this study is designed to examine the impact of justice forms on lecturers' work motivation at universities in Hanoi, Vietnam.

\section{Literature Review}

\section{Justice in organizations}

The idea of organizational justice is based on Equity Theory (Adams, 1965), which shows employees' judgment about equity and inequity from comparing themselves and others based on inputs and outcomes ratios. Organizational justice is mainly defined as employees' perceptions about how they are treated fairly or unfairly through action or decision-making in an organization related to rationality, equality, impartiality, and ethics (Greenberg, 1987).

In this study, "Awareness of justice" or "Feeling of fairness" was used to examine the effects of forms of justice on the level of work motivation. Three main aspects of organizational justice have been proposed in this model: justice in outcomes - the perceived fairness in the distribution of outcomes (e.g., pay, praise) (Colquitt et al., 2005; Greenberg, 2011), justice in the process - the perceived fairness in the implementation of management decisions that lead 
to outcomes (e.g., salary process, reward, and promotion) (Colquitt et al., 2005; Greenberg, 2011), and justice in treatment - the perceived fairness in respectful interactions that lecturers receive from the people who involved in their work (e.g., supervisors, colleagues) (Greenberg \& Colquitt, 2005). This model has been studied and applied in many studies related to organizational issues such as the payment, evaluation, appointment, and interactions within the organization (Colquitt et al., 2005; Nordhall \& Knez, 2018).

\section{Motivation of Employees}

As one of the most popular researched topics in education and psychology, motivation in the workplace has been generally viewed as engagements that influence someone to implement something by nature. Work motivation makes an organization think about encouraging employees to contribute their abilities and skills to realize their goals. Thus, motivation means a set of external and internal factors leading to behaviours related to establishing and orienting the form, timeframe, and action intensity (Pinder, 2008). According to Mitchell (1997; Saleem et al. 2010), motivation is considered as a process showing strengths, determination, and persistence in an individual's efforts towards achieving specific goals. Further, Steers \& Porter (1983) defined motivation as the desire and willingness of the person to try to expend their efforts to achieve organizational goals, it refers to how much a person tries to work hard and work well, and it is the impulse, consistency, and persistence in the work process. Based on these definitions, it can be interpreted that employees' motivation refers to reasons that emanate from the intrinsic values of employees themselves to choose and maintain their careers. Moreover, the intensity of motivation can be reflected in the desires, willingness, and efforts to achieve the organizational goals influenced by the internal or external environmental factors.

\section{The relationship between justice in paying salary, the process of payment, and work motivation}

In this study, justice in paying a salary is understood as the payments that lecturers receive are fair and reasonable compared to others with the same qualifications, experiences, positions, responsibilities, and others from different universities, and accurately reflect their efforts and capabilities. Additionally, perceptions of justice or fairness are also related to organizational procedures (Colquitt, 2005; Greenberg, 2011). Hence, the criteria and methods for paying salaries are required to be consistent, objective, and clear (Leventhal, 1980).

Numerous studies have been conducted to explain the importance of paying fairness to motivation in an organization. For example, Alam and Farid (2011) noted that paying salaries based on qualifications and providing incentives to good teachers will motivate them to continue to have high productivity and effectiveness in their performance. Aslam and Sadaqat (2011) observed that teachers in the University of Punjab, Pakistan are interested in fair outcomes and a fair process that leads to their outcomes. Other researchers have found a significant and positive relationship between pay fairness and the level of work motivation (Meng \& Wu, 2012; Stringer et al., 2011; Wenzel et al., 2017). Meng and Wu (2012) studied pay fairness and teachers' engagement in China. They found a positive correlation between 
pay fairness and teachers' engagement. The multiple regressions revealed a significant impact of the procedural pay fairness at $\mathrm{p}<.01$, conversely, perceived distributive pay fairness failed to show any significant relationship with job engagement. The finding of Stringer et al. (2011) studies showed that pay fairness positively affects employees' intrinsic motivation and increases work performance. In their study, Wenzel and his colleagues (2017) indicated a significant and positive correlation between perceived participatory, fair, and transparent in the pay system and intrinsic motivation.

\section{The relationship between justice in recognition and work motivation}

In this study, justice in recognition is considered how universities evaluate the lecturers' achievements in proportion, objectivity, consistency, and worthiness. According to the results of studies conducted by scholars such as (Ali \& Ahmad, 2009; Andrews, 2011), there is an indication that providing meaningful recognition and awards programs is a crucial factor for motivating teachers to work better, especially for excellent teachers. Additionally, Iliya and Ifeoma (2015) researched the motivational approach of teachers. They found that providing supportive teacher recognition is one of the major approaches to improving teachers' professional development. Further, Shah et al. (2012) argued that human resources are an essential part of any organization's success if the organization recognizes its employees' efforts and contributions and rewards them. Hence, fairness criteria for recognition are essential to make employees satisfied and keep them highly motivated to achieve organizational goals or even their objectives (Adams, 1965; Colquitt, 2005; Greenberg, 2011).

\section{The relationship between justice in promotion and work motivation}

The desire to study and develop professionally and gain a high position in the career is one of the most critical factors that strongly influence lecturers' work motivation (Sinclair, 2008). In this study, justice in promotion is understood as an opportunity for appointment to positions, training, and professional development that lecturers receive are fair and reasonable. Decisions making for promotions are based on accurate information, transparency, consistency, absence of bias, and in line with the ethical standards (Leventhal, 1980). Otherwise, promoting positions without basing on fair procedures and processes may cause teachers' negative attitudes, resistance, and non-cooperation (Sharon, 2015).

Numerous studies have shown that justice or fairness of the procedures used in promotion decisions is crucial for increasing teachers' motivation and satisfaction. For example, George and Sabapathy (2011) explored the relationship between work motivation and organizational commitment. The results indicated that if teachers see promotion opportunities clearly, they will be motivated and responsive to their organizations. Other researchers found a positive relationship between justice perceptions in promotion decisions and work motivation (GarciaIzquierdo, 2012; Lyu, 2016; Patras, 2020). Garcia-Izquierdo (2012) suggested that fairness in promotion is one of the most crucial factors directly related to organizational outcomes. They found that perceptions of justice in promoting are significant and positively correlated with employees' attitudes and behavior. Patras, 2020 studied organizational justice, job satisfaction, and Organizational Citizenship Behaviour (OCB). They found a moderate, positive, and 
significant relationship between organizational justice (with indicators such as promotion opportunities, application of rules, performance appraisal, superiors' attitudes, recognition of hard work) and teachers' motivation and satisfaction. The findings of Lyu's (2016) study showed that the positive correlation between all the sub-dimensions of organizational justice (including justice of the procedures used in decision making) and teachers' motivation, the multiple regression revealed a significant impact of procedural justice at $p<.01$.

\section{The relationship between justice in the attitude of colleagues and work motivation}

Basford and Offermann (2012) stated that the coworkers' relationship is an essential and integral part of people's lives. People always want to have a good relationship with others. According to Deci and Ryan (2002), people seek external relationships to satisfy both practical goals (e.g., knowledge and information) and psychological needs (e.g., intimate relationships and friends). In this study, justice in colleagues' attitude is understood as the recognition and evaluation that lecturers perceived from their colleagues about the capabilities and achievements are fair and accurate. These attitudes can be expressed through the sincere, friendly, and respectful behaviors of colleagues to lecturers.

The literature review suggested that the positive aspect of coworkers' relationship will build excitement in working, and workers will feel motivated, satisfied, and committed to their organization (Akman, 2018; Forret \& Love, 2007). According to Akman (2018), teachers' perceptions of fairness in colleagues' and managers' behaviour can be discussed as important factors that increase teachers' motivation and performance toward organizational effectiveness. They found a positive correlation between perceptions of justice in colleagues' and managers' behaviour and teachers' work motivation and job performance. Forret\& Love (2007) studied the relationship between employees' perceptions of justice and coworker relationships. They found that all sub-dimensions of organizational justice (distributive, procedural, and interaction) are significant and positively correlated with coworkers' and work groups' trust and morale.

\section{The relationship between justice in the behaviour and treatment of leaders and work motivation}

The relationship between forms of justice or fairness and teachers' work motivation across the impacts of principals and supervisors' treatments has been proved in different studies. Namely, it has been indicated that teachers' level of effort, performance, and work motivation increase when they perceived the fair attitudes and treatments from their leadership (CohenCharash\& Spector, 2001; Colquitt, 2005, Greenberg, 2011; Oren et al., 2013). Otherwise, leadership's unfair attitudes and treatments are the leading cause of reduced efforts, motivation, and decreased job interest and performance (Mullins, 2007). Lyu (2016) found that perceptions of justice in behavior and treatment of leaders and supervisors are moderate positively correlated with teachers' engagement. In other words, the more supervisors treat teachers with respect, politeness, and dignity, the more effort teachers will expend in their job. Akman (2018) investigated the relationship between perceptions of fairness in attitude and 
supervisors' treatment, and teachers' motivation. They found that perceptions of supervisors' fair attitudes and teachers' motivation have a moderate positive correlation.

\section{The relationship between justice in the student's attitude and work motivation}

Justice or fairness in the students' attitude and treatment can be defined as the sense of respect, honesty, and sincerity that the lecturers perceived from their students. These feelings can be reflected in a student's learning attitude. Numerous studies have shown the importance of the attitude of students in increasing teachers' motivation. For example, Lee et al. (1991) emphasized that one of the factors influencing a teachers' efficacy and satisfaction is the student's characteristics. The positive attitude of students toward learning has a substantial impact on the teachers' motivation and satisfaction. Additionally, a study was done by Sinclair (2008) in Australia on students' influence on teachers' motivation and commitment to teaching. The author noted that the motivation factors for a person who wants to become a teacher are the desire to work with young and always happy and ambitious students.

\section{The relationship between justice in the attitude of society and work motivation}

Justice in society's attitude is understood as respect and appreciation for the teaching profession's position in society. This attitude can be reflected in friends' and relatives' positive attitudes and government remuneration policies to a teaching career.

Educators played a pivotal role in shaping the next generation by providing high-quality education for students (UNESCO, 2000). In other words, they make a contribution and influence society in the future. Therefore, the attitude of society has an impact on the work motivation of lecturers. The literature review suggested that when teachers perceive they are not treated fairly, or their career is disregarded by society, their performance and positive attitude towards work tend to decline (Alam \& Farid, 2011). Davidson (2007) investigated the pivotal role of motivation on the quality of teachers. The author implied that good appreciation from society about a teaching career is a crucial factor that positively influences teachers' motivation. Naseer et al. (2012) invested in influencing teachers' motivation in Kohat, Pakistan. They found that teachers' social status is one of the most critical factors that enhance their motivation and performance and stick with the teaching profession. Thus, teachers always need to be judged and treated fairly by society, bringing the lecturer a motivation to work (Alam\& Farid, 2011).

\section{Methodology and Procedures}

The study was conducted in 2019 in 16 universities (including 11 public universities and five non-public universities) in Hanoi's capital city by applying the random sampling technique. The survey of questionnaires was done in Vietnamese, the official language, and sent to all the lecturers present at the university campuses at the time of data collection. A total of 500 questionnaires were distributed to the respondents, and the returned response rate was $87,8 \%$ (439 responses), and 416 were usable in this research. 
The Level of Work motivation: measured using six main items modified from Steers and Porter (1983), which measured distinct motivation dimensions. These items focus on identifying the lecturers' work motivation, consistency, and persistence in completing the task and meeting the organization's goals. Participants responded to items such as "I make a sustained effort to finish off work in any situation" by marking their responses on a 5-point Likert scale $(1=$ strongly disagree to $5=$ strongly agree $)$.

Perceptions of justice or fairness: The perceptions of lecturers on four forms of justice, which are justice in paying salary, the process of paying salary, recognition, and opportunities for promotion scale items used in this study were adapted from Colquitt (2001); and Leventhal (1980). These modified questionnaires consisted of $6,4,7$, and 7 items, respectively. The perceptions of justice in the behaviour and treatment of direct leadership, colleagues, and students were measured by adapting the scale of Niehoff and Mooman (1993); and Colquitt (2001) with 12, 7, and 5 items, respectively. Finally, the forms of justice in the society's attitude and assessment were measured by developing the ideas proposed by Tyler (1994); Tyler \& Lind (1992). These forms comprise seven items. All the items in this study were developed using a 5 point Likert scale $(1=$ strongly disagree to $5=$ strongly agree).

\section{Results and Discussion}

\section{Regression Analysis for Perceptions of Justice on the Level of Work Motivation}

For testing the hypotheses of this study, a regression was conducted using IBM SPPS ver. 25. Table 1 presents a regression analysis, which consists of two models to get the best solution for this study. A zero-order correlation coefficient $(r)$, the coefficient of determination $\left(R^{2}\right)$, standardized coefficients $(\beta)$, standard errors $(S . E)$, and probability values $(p)$ are provided in Table 1. In Model 1, a multiple regression analysis was conducted to determine the relationship between eight potential predictors and the level of work motivation by controlling three demographics variables (gender, qualification level, and type of university). According to data presented in Table 1, Model 1 multiple regression revealed the significant and positive impact of justice in paying salary $(\beta=.276 ; p<.000)$, recognition $(\beta=.086 ; p<.024)$, promotion $(\beta=.314 ; p<.000)$, and the behaviour and treatment of direct leadership on the level of work motivation $(\beta=.097 ; p<.012), F(11,404)=229.848, p=0.000$ with $95 \%$ confidence interval level, conversely, justice in the processing of paying, justice in the attitude of colleagues, students, and society's attitudes and assessment failed to show any significant relationship with the level of work motivation. $R^{2}$ is .862 for the final model that suggests that the model is a very good fit.

Table 1: Multiple Regression Predicting Lecturer's Work Motivation $(n=416)$.

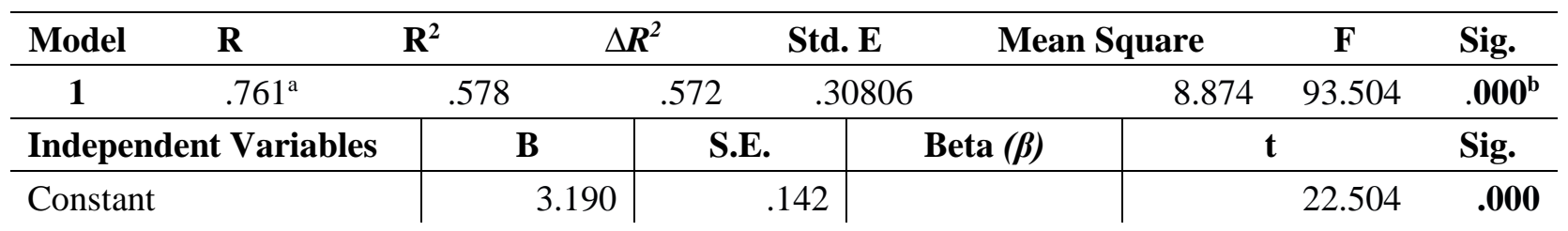




\begin{tabular}{l|r|r|r|rr} 
Gender & .436 & .034 & .462 & 12.843 & $\mathbf{. 0 0 0}$ \\
Age & -.002 & .023 & -.008 & -.106 & .916 \\
Work Experience & -.35 & .030 & -.088 & -1.151 & .251 \\
Qualification Level & .071 & .041 & .072 & 1.719 & .086 \\
Job Title & .227 & .041 & .264 & 5.594 & $\mathbf{. 0 0 0}$ \\
Type of University & -.294 & .034 & -.310 & -8.763 & $\mathbf{. 0 0 0}$ \\
\hline
\end{tabular}

Dependent Variable: The level of Work Motivation

Demographic Variables: Job Title, Gender, Work Experience, Qualification Level, Age

Source: Authors

Table 2: Multiple Regression Showing Results for the Impact of Perceptions of Justice on the Level of Work Motivation among University Lecturers in Hanoi $(n=416)$.

\begin{tabular}{|c|c|c|}
\hline Variables & Model $1^{c}$ & Model $2^{d}$ \\
\hline \multicolumn{3}{|l|}{ Control Variables } \\
\hline Gender & $.135^{*}$ & $.141 *$ \\
\hline Job Title & $.111^{*}$ & $.118^{*}$ \\
\hline Type of university & $-.128 *$ & $-.128 *$ \\
\hline \multicolumn{3}{|l|}{ Independent Variables } \\
\hline 1. Justice In Payment & $.276 *$ & $.289 *$ \\
\hline 2. Justice In Processing Of Payment & .040 & \\
\hline 3. Justice In Recognition & $.086 * *$ & $.079 * *$ \\
\hline 4. Justice In Opportunities For Promotion & $.314 *$ & $.316^{*}$ \\
\hline 5. Justice In the Attitude Of Colleagues & -.017 & \\
\hline $\begin{array}{l}\text { 6.Justice In the Behaviour And Treatment Of Direct } \\
\text { Leadership }\end{array}$ & $.097 * *$ & $.119 *$ \\
\hline 7.Justice In the Students' Attitudes & .051 & \\
\hline 8.Justice In the Society's Attitudes And Assessment & -.041 & \\
\hline \multicolumn{3}{|l|}{ Results } \\
\hline$R^{2}$ & .862 & .860 \\
\hline $\boldsymbol{F}$ & 229.848 & 358.036 \\
\hline S.E & .114 & .113 \\
\hline
\end{tabular}

$* * p=<0.05, * p=<0.01$

Source: Authors

Table 2 also revealed model 2 that regressed all predictor variables of work motivation, except justice in the processing of a payment, justice in colleagues' attitude, justice in the students' attitudes, and justice in society's attitudes and assessment. Thus, the second model indicated that four components selected by the model accounted for $86.0 \%\left(R^{2}=.860\right)$ of the total variance of the level of work motivation among university lecturers in Hanoi. Multiple regression revealed significant and positive effect of justice in paying salary $(\beta=.286$; $p<.001)$, recognition $(\beta=.079 ; p<.014)$, promotion $(\beta=.316 ; p<.001)$, and the behaviour and treatment of direct leadership on the level of work motivation $(\beta=.119 ; p<.001), F(7,408)=$ 
358.036, $p=0.000$ with $95 \%$ confidence interval level. The results indicated that the perceptions of promotion, paying salary, recognition, and the behaviour and treatment of the lecturers' direct leadership are justly higher; this will increase their work motivation proportionally.

Based on the two models (see Table 2), the main hypotheses tests are provided in Table 3.

Table 3: Hypotheses Testing

\begin{tabular}{clc}
\hline No. & \multicolumn{1}{c}{ Hypotheses path } & Final remark \\
\hline 1 & Justice in Payment $\rightarrow$ the Work Motivation of Lecturers & Supported \\
2 & Justice in Processing of Payment $\rightarrow$ the Work Motivation of Lecturers & Not Supported \\
3 & Justice in Recognition $\rightarrow$ the Work Motivation of Lecturers & Supported \\
4 & Justice in Opportunities for Promotion $\rightarrow$ the Work Motivation of Lecturers & Supported \\
5 & Justice in the attitude of colleagues $\rightarrow$ the Work Motivation of Lecturers & Not Supported \\
6 & $\begin{array}{l}\text { Justice in the Behavior and Treatment of Leadership } \rightarrow \text { the Work Motivation } \\
\text { of Lecturers }\end{array}$ & Supported \\
7 & $\begin{array}{l}\text { Justice in Student's Feedback } \rightarrow \text { the Work Motivation of Lecturers } \\
8\end{array}$ & Justice in the Society's Attitudes and Assessment $\rightarrow$ the Work Motivation of \\
& Lecturers & Not Supported \\
\hline
\end{tabular}

Source: Authors

\section{Finding \& Discussion}

The primary purpose of this study was to find out the impact of perceptions of justice in paying salary, the process of paying salary, recognition, opportunities for promotion, the attitudes and treatments of colleagues, students, leadership, and society on the level of work motivation among lecturers working at universities in Hanoi, Vietnam. Our results of the study support findings which have been carried out by other theorists and researchers, stating that justice or fairness in an organization is associated with work motivation (e.g., Adams, 1965; Akman, 2018; Greenberg \& Colquitt, 2005; Greenberg 2011; Latham \& Pinder, 2005; Tadesse, 2020).

The findings revealed a moderate positive and significant relationship between perceptions of justice or fairness in opportunities for promotions and the level of work motivation. The findings implied that the high perceptions of justice in opportunities for promotions resulted in lecturers' behaviour in Hanoi universities as it positively enhances lecturers' work motivation. These findings are supported by Garcia-Izquierdo (2012), Lyu (2016), Patras's (2020) studies. Additionally, in this study, almost all lecturers showed that they understand clearly the mechanisms and policies for appointing staff in schools and agreed that promotion fairness has a significant influence on their work motivation. The highest impact of justice or fairness in promotion opportunities explains that it is more critical for Vietnamese lecturers to have fairness in promotion-related opportunities following a fair evaluative mechanism to motivate lecturers. Depending on these findings, it can be interpreted that lecturers have a positive approach toward the schools in terms of justice in promotion-related opportunities. This result can also be accepted as an indicator that lecturers' perceptions of justice in the promotion can be discussed as essential factors that increase the school's effectiveness. This conclusion was supported in the literature. Providing fairness in promotion activities brings 
improvement in employee's behavior and motivation, especially for a young teacher, according to Sinclair (2008). George and Sabapathy (2011) declared that if teachers see opportunities for promotion at their work, they will be motivated to work better and be more responsive to their organizations. It is stated that fairness treatment in terms of performance appraisal, determining policies will make teachers the maximum to their work, be more responsible for their tasks, and contribute to their success (Patras, 2020).

Another result of this study is embodied in the concept that when lecturers face justice or fairness in payment, it increases their motivation. The findings revealed a positive relationship between perceptions of justice in paying salary and lecturers' work motivation. If the payments that lecturers receive are fair and reasonable and reflect their efforts and capabilities accurately, it improves lecturers' behavior and boosts their motivation to do the task better. The results agree with findings by other researchers stating that that perception of justice or fairness in payment is associated with the level of work motivation (Alam\& Farid, 2011; Aslam \&Sadagat, 2011). This finding is also in line with Wenzel and his colleagues (2017) when he measured pay fairness and intrinsic motivation and found that this relationship is significantly moderate. Pay fairness is one of the crucial factors that directly influence employees' work motivation and job satisfaction, and those who perceived pay was not fair or not reflect their efforts generally tend to be demotivated and dissatisfied with their current job, which Stringer et al. (2011) investigated the relationship between pay satisfaction, motivation, and job satisfaction is also compatible with the present study. However, these results contradict Meng \& Wu's (2012) study, while they found no significant relationship between distributive pay fairness and teachers' engagement in China. The study also showed that most lecturers clearly understand the pay mechanism and policies expressed in high perceptions of the procedural pay fairness; however, as the results of regression analysis indicated that perceptions of justice in paying salary have given non-significant on their work motivation. Teachers' procedural pay fairness is significantly moderate, which Meng \& Wu (2012) investigated the relationship between pay fairness and teachers' engagement contradicts the present study. From these results, it can be thought that pay fairness is different based on an individual's perceptions. While some lecturers emphasize the rules and procedures within a university (the aspect of procedural justice), others pay attention to how they are ultimately rewarded (distributive justice).

Besides, whether the relationship between perceptions of justice or fairness in attitude and treatment of people involved in lecturers' work (such as colleagues, leaders, students, and society) is associated with lecturers' work motivation or not has also been investigated. According to the results, it has been determined that justice or fairness in leaders' attitudes and behaviours has a positive relationship with work motivation. Results that are in line with the finding have been obtained in Cohen-Charash \& Spector (2001), Colquitt (2005), Greenberg, 2011, Oren et al. (2013) 's studies. Positive and low correlations between leadership and lecturers' work motivation have been seen given the present study. However, Akman (2018) and Lyu (2016) found out that this relationship is significantly moderate. Hence, it can be said that even if the perceptions of justice in attitudes and treatment of leadership increase to a barely higher level, it also increases lecturers' work motivation and 
performance. Additionally, the findings also showed that while the relationship between perceptions of lecturers' justice in attitudes and treatment by leadership and work motivation has proved significant with positive correlations, perceptions of justice in attitudes and assessments of colleagues, students, and society have contributed to the non-significant impact on lecturers' work motivation. Besides, it was also found that there was no significant correlation between lecturers' work motivation and the effect of justice in attitude and assessments from society in this present study. These findings contradict Alam and Farid's (2011) study, which suggests that lecturers' work motivation increases when face fair judgment and treatment about teaching career's status from society. The regression analysis indicated no significant correlation between perceptions of justice in attitudes and assessments of colleagues, students, and society on lecturers' work motivation in the present study. However, the study suggests that the relationship between these variables should not be neglected. The relationship between perceptions of justice in attitudes of colleagues (Akman, 2018; Forret \& Love, 2007), justice in attitudes of students (Lee et al., 1991; Sinclair, 2008), and justice in attitude and evaluation of society (Alam \& Faird, 2011; Davidson, 2007; Naseer et al., 2012) and teachers' work motivation has been established before this study. In that, the impact of colleagues, students, and society has become a critical role in increasing employees' motivation.

Perceptions of justice in recognition also have a fair contribution toward increasing work motivation among lecturers. According to the results of partial correlation, it has been seen that the level of work motivation is partly provided by justice or fairness in recognition. In other words, the perception of recognition fairness is a significant variable in enhancing lecturers' work motivation. The findings support the theories and studies of Ali\& Ahmad (2009), Andrews (2011), and Shah et al. (2012), who suggested that providing meaningful teacher recognition is an essential approach for increasing teachers' motivation and performance. This situation will improve teachers' professional development (Iliya \& Ifeoma, 2015) and students' learning outcomes (Andrews, 2011). Otherwise, lecturers' efforts, performance, and motivation can be damaged when facing unfair recognition (Adams, 1965; Colquitt, 2005; Greenberg, 2011). It can be stated that fair criteria for recognition, which is one of the crucial factors in the education system, are directly associated with lecturers' level of work motivation.

Finally, for testing the hypotheses of the study, the model provided a significant and positive impact of perceptions of justice in paying salary, recognition, opportunities for promotion, and the behaviour and treatment of direct leadership on the level of work motivation among university lecturers in Hanoi with the overall effect of $86.0 \%$, p-value of 0.000 , therefore, $\mathrm{H} 1$; H3; H4; and H6 are supported.

\section{Conclusion and Suggestion}

Lecturers play a vital role in the field of education and training. When choosing teaching as a career, like other professions, lecturers also expect to have adequate support, treatment, and resources to help them develop themselves and contribute to the school's success. Overall, the perceptions of justice or fairness in schools implied a significant and positive impact on the 
level of work motivation among lecturers. Hence, the role of justice or fairness in increasing lecturers' work motivation should not be neglected and needs to be paid more attention. The study also showed that Vietnamese lecturers are more concerned with non-monetary than monetary compensation, such as promotions, training, and professional development opportunities. Thus, schools should ensure that lecturers are received opportunities for promotions, studying and training, professional development, and gaining a high position fairly and accurately. In this study, it is recommended that if the school does not have resources and abilities to pay more to lecturers, they could establish the methods and policies of selection and evaluation and fairness, clarity, and transparency, which maintains the entitlements of the lecturer as far as possible. Notably, the fairness in paying does not mean lecturers will receive the same pay as others, but any difference in compensation should be explained clearly and accurately. Besides, creating and maintaining a positive relationship between principals, supervisors, and lecturers are also necessary. These things can help to increase the lecturers' level of work motivation. Finally, this study's results only showed the lecturers' perceptions about specific forms of justice; it is suggested for further study that other issues related to justice or fairness in an organization are also worth investigating.

This study presents implications for Vietnam's higher education authorities. The results might be of interest for any project aiming at motivating faculty and improving their working conditions. The country loses dozens of academicians who might create the country's vital human capital, and hence this study provides a platform for further research in the field. Thus, policy makers are suggested to use interventions, either monetarily or non-monetarily, to boost lecturers working performance.

\section{Conflict of Interest}

The authors of the article declare no conflict of interest.

\section{Funding}

The costs of conducting the study and for publishing this article are of the authors.

\section{Availability of Data and Material}

The data that support the findings of this study are available from the corresponding author, upon reasonable request.

\section{References}

Adams, J. S. (1965). Inequity in social exchange. Advances in experimental social psychology, 267-299. DOI: 10.1016/s0065-2601(08)60108-2.

Akman, Yener. (2018). The Investigation of The Relationships Between Organizational Justice, Work Motivation, and Teacher Performance. Cukurova University Faculty of Education Journal. 47(1). 164-187. DOI: 10.14812/cuefd.371642

Alam, M. T., \& Farid, S. (2011). Factors affecting teachers' motivation. International Journal of Business and Social Science, 2(1), 298-304. 
Ali, R., \& Ahmad, M. S., (2009), "The Impact of Reward and Recognition Programs on Employee's Motivation and Satisfaction: An Empirical Study", International Review of Business Research Papers, 5 (4), pp.270-279.

Andrews, H. A. (2011). Supporting Quality Teaching with Recognition. Australian Journal of Teacher Education, 36(12). http://dx.doi.org/10.14221/ajte.2011v36n12.5

Anh, Le \& Hayden, Martin. (2017). The Road Ahead for the Higher Education Sector in Vietnam. Journal of International and Comparative Education. 6(2) 77-89. DOI: 10.14425/jice.2017.6.2.77.

Aslam R. \&Sadaqat S (2011). Investigating the Relationship of Organizational Justice on Organizational Citizenship Behavior among Teaching Staff of the University of Punjab. European Journal of Scientific Research ISSN 1450-216X Vol.57 No.1 (2011), pp.5367.

Basford, T.E and Offermann, L. (2012), "Beyond leadership: The impact of coworker relationships on employee motivation and intent to stay', Journal of Management \& Organization, 18(6), pp. 807-817.

Cohen-Charash Y, \& Spector, P. E. (2001). The Role of Justice in Organizations: a MetaAnalysis.Organizational Behavior and Human Decision Process, 86(2), 278-321. DOI: 10.1006/obhd.2001.2958

Colquitt, J. (2001). On the dimensionality of organizational justice: A construct validation of a measure. Journal of Applied Psychology, 86(3), 386-400. DOI: 10.1037//00219010.86.3.386

Colquitt, J. A., Greenberg, J., and Zapata-Phelan, C. P. (2005). "What is organizational justice? a historical overview," in Handbook of Organizational Justice, eds J. Greenberg and J. A. Colquitt (Mahwah, NJ: Lawrence Erlbaum Associates Publishers), 3-56.

Euan Davidson (2007) The Pivotal Role of Teacher Motivation in Tanzanian Education, The Educational Forum, 71:2, 157-166, DOI: 10.1080/00131720708984928

Forret, M., \& Love, M. S. (2007), "Employee justice perceptions and coworker relationships", Leadership and Organization Development Journal, 29(3), pp.248-260. DOI: 10.1108/01437730810861308

Garcia-Izquierdo, Antonio \&Moscoso, Silvia \& Ramos-Villagrasa, Pedro J.. (2012). Reactions to the Fairness of Promotion Methods: Procedural Justice and Job Satisfaction. International Journal of Selection and Assessment. DOI: 10.1111/ijsa.12002.

George, L. and Sabapathy, T. (2011), "Work Motivation of Teachers: Relationship with Organizational Commitment", Canadian Social Science, 7(1), pp. 90-99.

Greenberg, J. (1987). A taxonomy of organizational justice theories. Academy of Management Review, 12(1), 9-22. DOI: 10.5465/AMR.1987.4306437.

Greenberg, J. (2011). Organizational justice: the dynamics of fairness in the workplace. APA Handbook of Industrial and Organizational Psychology, Vol. 3 Maintaining, Expanding, and Contracting the Organization., 271-327. DOI: 10.1037/12171-008.

Greenberg, J., \& Colquitt, J. A. (Eds.). (2005). Handbook of organizational justice. Lawrence Erlbaum Associates Publishers. 
Hamano, Takashi. (2008). Educational reform and teacher education in Vietnam. Journal of Education for Teaching. 34. 397-410. DOI: 10.1080/02607470802401693.

Henle, C. A. (2005). Predicting workplace deviance from the interaction between organizational justice and personality. Journal of Managerial Issues, 17(2), 247-263.

Iliya, A., \&Ifeoma, L.G. (2015). Assessment of Teacher Motivation Approaches in the Less Developed Countries. Journal of Education and Practice, 6, 10-17.

Jesus, Saul \& Lens, Willy. (2005). An Integrated Model for the Study of Teacher Motivation. Applied Psychology. 54(1). 119 - 134. DOI: 10.1111/j.1464-0597.2005.00199.x.

Latham, G. P., \&Pinder, C. C. (2005). Work motivation theory and research at the dawn of the twenty-first century. Annual Review of Psychology, 56, 485-516. DOI: 10.1146/annurev.psych.55.090902.142105.

Lee, V.E., Dedrick, R.F., and Smith, J.B (1991), "The effect of the social organization of school on teachers' efficacy and satisfaction", Sociology of Education, 64(3), 190. DOI: $10.2307 / 2112851$.

Leventhal, G. S. (1980). What Should Be Done with Equity Theory? Social Exchange, 27-55. DOI: 10.1007/978-1-4613-3087-5_2

Levesque, M., Blais, M. R., \& Hess, U. (2004). Motivational dynamic of burnout and wellbeing in African teachers. Canadian Journal of Behavioral Science, 36(3), 190-201. DOI: $10.1037 / \mathrm{h} 0087229$

Lyu, X. (2016). Effect of organizational justice on work engagement with psychological safety as a mediator: Evidence from China. Social Behavior and Personality: An International Journal, 44(8), 1359-1370. DOI:10.2224/sbp.2016.44.8.1359

Meng, Fanrong\& Wu, Jiannan. (2012). Merit Pay Fairness, Leader-Member Exchange, and Job Engagement: Evidence From Mainland China. Review of Public Personnel Administration. 35(1). DOI: 10.1177/0734371X12453057

Mitchell, T.R, Terrence R., Cummings, L.L and Staw, B.M (1997), "Matching motivation strategies with organizational contexts". Research in organizational behavior, 19, pp.57-149, CT: JAI Press, Greenwich.

MOET (Ministry of Education and Training), (2005). Decision No. 14/NQ-CP Dated November 2nd, 2005 on basic and comprehensive reform of Higher Education in Vietnam for the period of 2016 - 2020. https://thuvienphapluat.vn/van-ban/giaoduc/Nghi-quyet-14-2005-NQ-CP-doi-moi-co-ban-va-toan-dien-giao-duc-dai-hoc-VietNam-giai-doan-2006-2020-5013.aspx

Mullins, L. J. (2007). Management and Organizational Behaviour. (8th ed.), Harlow: Pearson Education Limited.

Naseer Ud Din, M., Tufail, H., Shereen, S., Nawaz, A., \& Shahbaz, A. (2012).Factors Affecting Teacher Motivation at Secondary School Level in Kohat City. InterDisciplinary Journal of Contemporary Research in Business, 3 (10), pp 442-449.

Ngo, D. D. (2006). Higher education in Southeast Asia: An overview. Higher education in South-East Asia. Asia-Pacific program of educational innovation for development, United Nations Educational, Scientific, and Cultural Organization (pp. 219-250). UNESCO Bangkok: Bangkok, Thailand. 
Niehoff, B. P., \& Moorman, R. H. (1993), "Justice as a mediator of the relationship between methods of monitoring and organizational citizenship behavior", Academy of Management Journal, 36(3), pp.527-556. DOI: 10.2307/256591.

Nordhall, O., \&Knez, I. (2018). Motivation and justice at work: The role of emotion and cognition components of personal and collective work identity. Frontiers in Psychology, 8, Article 2307. DOI: 10.3389/fpsyg.2017.02307.

Oren, L., Tziner, A., Nahshon, Y. and Sharoni, G., (2013), "Relations between OCBs, organizational justice, Work motivation and Self- efficacy", The Protection of Consumer Rights in the Field of Economic Services of General Interest, 15(34), pp.505-516.

Patras, Yuyun\&Sutisna, Entis\&Afif, Muhammad. (2020). Influence of Organizational Justice and Job Satisfaction on Teachers' Organizational Citizenship Behavior. DOI: 10.2991/assehr.k.200513.005.

Pinder, C.C., (2008), Work motivation in organizational behavior, 2nd ed. Psychology Press, New York.

Saleem , \& M. Azeem, 2010. Effect of Work Motivation on Job Satisfaction in Mobile Telecommunication Service Organizations of Pakistan. DOI: 10.5539/ijbm.v5n1 1p213

Shah, M.J, Rehman, M.U, Akhtar, G., Zafar, H. and Riaz, A. (2012), "Job satisfaction and Motivation of Teachers of Public Education Institutions", International Journal of Business and Social Science, 3(8), pp.271-281.

Sharon Thabo Mampane (2015) Procedures and Processes Followed in the Appointment of Principals for School Leadership and Management, Journal of Social Sciences, 42:3, 239-245, DOI: 10.1080/09718923.2015.11893411

Scimago Institutions Ranking. (2017). Country Rankings for Education. Retrieved from: https://www.scimagojr.com/countryrank.php?year=2017\&category=3304 Accessed 23 August 2017.

Sinclair (2008), "Initial and changing student, teacher motivation and commitment to teaching", Asia-Pacific Journal of Teacher Education, 36(2), 79-104. DOI: 10.1080/13598660801971658

Steers, R.M., \& Porter, L.W. (1983). Motivation: New directions for theory and research. Academy of Management Review, 17(1), 80-88.

Stringer, C., Didham, J. and Theivananthampillai, P. (2011), "Motivation, pay satisfaction, and job satisfaction of front-line employees", Qualitative Research in Accounting \& Management, 8(2), 161-179. DOI: 10.1108/11766091111137564.

Tadesse, E. (2020). Teachers' Organizational Commitment at Secondary School in Addis Ababa, Ethiopia. International Journal of Education and Research,Vol. 7 No. 4.

Tyler, T. R. (1994), "Psychological models of the justice motive: Antecedents of distributive and procedural justice", Journal of Personality and Social Psychology, 67(5), pp. 850863. DOI: $10.1037 / 0022-3514.67 .5 .850$

Tyler, T. R. \& Lind E. A., (1992), "A Relational Model of Authority in Groups". Advances in experimental social psychology, Volume 25, pp. 115-191. DOI: 10.1016/S00652601(08)60283-X

Vroom, VH. (1964). Work and motivation. New York: John Wiley \& Sons Inc. 
Wenzel, A.-K., \& Krause, T.A., \& Vogel, D. (2017). Making Performance Pay Work: The Impact of Transparency, Participation, and Fairness on Controlling Perception and Intrinsic Motivation. Review of Public Personnel Administration, $0734371 X 1771550$. DOI: $10.1177 / 0734371 X 17715502$.

World Bank (2008). Vietnam: Higher education and skills for growth. Washington, D.C. : World Bank Group. http://documents.worldbank.org/curated/en/439591468338403597/Vietnam-Highereducation-and-skills-for-growth 